\title{
Nutritional values of swamp grasses as feed for Pampangan Buffaloes in South Sumatra, Indonesia
}

\author{
MUHAKKA ${ }^{1, \boldsymbol{v}}$, RUJITO AGUS SUWIGNYO ${ }^{2}$, DEDIK BUDIANTA ${ }^{3}$, YAKUP $^{2}$ \\ ${ }^{1}$ Department of Animal Husbandry, Faculty of Agriculture, Universitas Sriwijaya. Jl. Palembang-Prabumulih Km 32, Inderalaya, Ogan Ilir 30662, \\ South Sumatra, Indonesia. Tel./fax.: +62-711-581106. ^email: muhakka@fp.unsri.ac.id \\ ${ }^{2}$ Department of Agronomy, Faculty of Agriculture, Universitas Sriwijaya. Jl. Palembang-Prabumulih Km 32, Inderalaya, Ogan Ilir 30662, \\ South Sumatra, Indonesia \\ ${ }^{3}$ Department of Soil Science, Faculty of Agriculture, Universitas Sriwijaya. Jl. Palembang-Prabumulih Km 32, Inderalaya, Ogan Ilir 30662, \\ South Sumatra, Indonesia
}

Manuscript received: 17 October 2019. Revision accepted: 8 February 2020.

\begin{abstract}
Muhakka, Suwignyo RA, Budianta D, Yakup. 2020. Nutritional values of swamp grasses as feed for Pampangan Buffaloes in South Sumatra, Indonesia. Biodiversitas 21: 953-961. This study was aimed at determining the types and quality of vegetation in the swamp area, which could be used as sources of roughage for Pampangan buffaloes in South Sumatra. In this descriptive study, Results showed that the highest crude protein and ether extract contents, 20.56 and $2.92 \%$, respectively, were found in (Neptunia oleracea). The highest ash content of $25.19 \%$ was found in Cyperus digitatus. The lowest fiber content $(11.01 \%)$ was found in Ludwigia hyssopifolia, which also had the lowest content of Neutral Detergent Fiber (NDF) (40.64\%). Hemicellulose content was found to be highest (37.14\%) in Leersia hexandra. The lowest ADF (23.66\%) and lignin (14,84\%) contents were found in Nymphaea lotus. N. oleracea was found to have the lowest content $(27.08 \%)$ of cellulose. It was concluded that the swamp vegetation found in this study consisted of 17 species of grasses and herbs (89.47\%) and two species of legumes (10.53\%). C. digitatus and L. hyssopifolia were found to have the best nutritional values. Dominant and palatable vegetation with good nutritional values, which were potential to be used as sources of roughage for Pampangan buffaloes, were Hymenachne acutigluma, Oryza rufipogon, Hymenachne amplexicaulis, Polygonum barbatum, and Eleocharis dulcis.
\end{abstract}

Keywords: Feed, nutritional value, Pampangan buffalo, swamp grass

\section{INTRODUCTION}

The availability of roughage as the main feed for ruminants depends considerably on seasons. During the rainy season, it is abundant, but during the dry season, the availability of grasses/herbs and legumes is lacking. The limited supply of roughage may hamper productivity including the reproductive performance of ruminants including buffaloes.

In South Sumatra, Pampangan buffalo is potential germplasm that needs to be preserved and developed. There were 37,405 Pampangan buffaloes in 2016, and this population increased by $3.97 \%$ to 38,952 in 2017 . In 2017, of this population, $11,150(28.63 \%)$ and 2,227 (5.72\%) were found in Ogan Komering Ilir District and Banyuasin District, respectively (Dinas Peternakan Sumatera Selatan 2014). The population and productivity of Pampangan buffaloes need to be improved, and for this purpose, feed is an important factor to consider. Pampangan buffaloes feed mostly on roughage from the swamp, grassland to meet their upkeeping and reproductive needs.

In Indonesia, there are 13.27 million hectares of lowland swamp areas. Only 4 million hectares of these areas have been developed and cultivated by the community and private sectors (2.6 million hectares) and the government assistance (1.3 million hectares) (BPS 2010; Mulyani and Sarwani 2013). In Sumatra, the largest lowland swamp area of 2.98 million hectares is found in South Sumatra, but only 298,189 hectares of it have been utilized (BPS 2014). In order to utilize the potential swamp area as a feed source for Pampangan buffaloes, a study on vegetation as sources of roughage in lowland swamp areas that include vegetation identification and nutritional quality determination needs to be conducted.

In the previous study, some swamp grasses, including H. amplexicaulis (Rostini et al. 2014; Muhakka et al. 2015), I. rugosum and L. hexandra (Ali et al. 2012) were identified. However, more swamp vegetation has not been identified. For example, $P$. barbatum, $C$. digitatus, $R$. corymbosa This study was conducted to identify the types and nutritional values of vegetation that could be used as sources of roughage feed for Pampangan buffaloes in South Sumatra. This information was important to support the productivity improvement of Pampangan buffaloes as germplasm in South Sumatra, Indonesia. In this study, some new swamp forages were found, and they were not stated in the previous study. 


\section{MATERIALS AND METHODS}

\section{Area study}

This study was a descriptive study to assess the types and nutritional values of vegetation, which were dominant and palatable as sources of roughage feed for Pampangan buffaloes. Vegetation samples were taken from grazing areas of Pampangan buffaloes in Rambutan Village and Pulau Layang Village, South Sumatra, Indonesia (Figure 1) from April to Juni 2017. Vegetation samples for nutrient analysis were obtained by following procedures: (i) vegetation collection was done based on estimated growth age (young age, middle age, and old age based on physical appearance), (ii) collected samples of each vegetation was composited, and (iii) samples were chopped into small sizes, and then homogenized.
For each vegetation, $1 \mathrm{~kg}$ sample was taken randomly and sent to the laboratory for oven drying at $105^{\circ} \mathrm{C}$, until a constant weight was obtained and dry matter content was determined. Samples were then ground for nutrient content determination by using proximate and Van Soest analyses (Syarifuddin and Wahdi 2010). Sample analyses of crude protein, fiber, ether extract, and ash contents were conducted in Laboratory of Dairy Nutrition, Department of Nutrition and Feed Technology, Institut Pertanian Bogor (IPB), Bogor, Indonesia, while analyses of NDF, ADF, hemicellulose, cellulose, and lignin were conducted in Biotechnology Assessment Laboratory, Research Center for Biotechnology, Indonesian Institute of Sciences (LIPI), Cibinong, Bogor, Indonesia; and analysis of soil was conducted in Laboratory of Soil Chemistry, Biology, and Fertility, Department of Soil, Faculty of Agriculture, Sriwijaya University, Ogan Ilir, Indonesia.
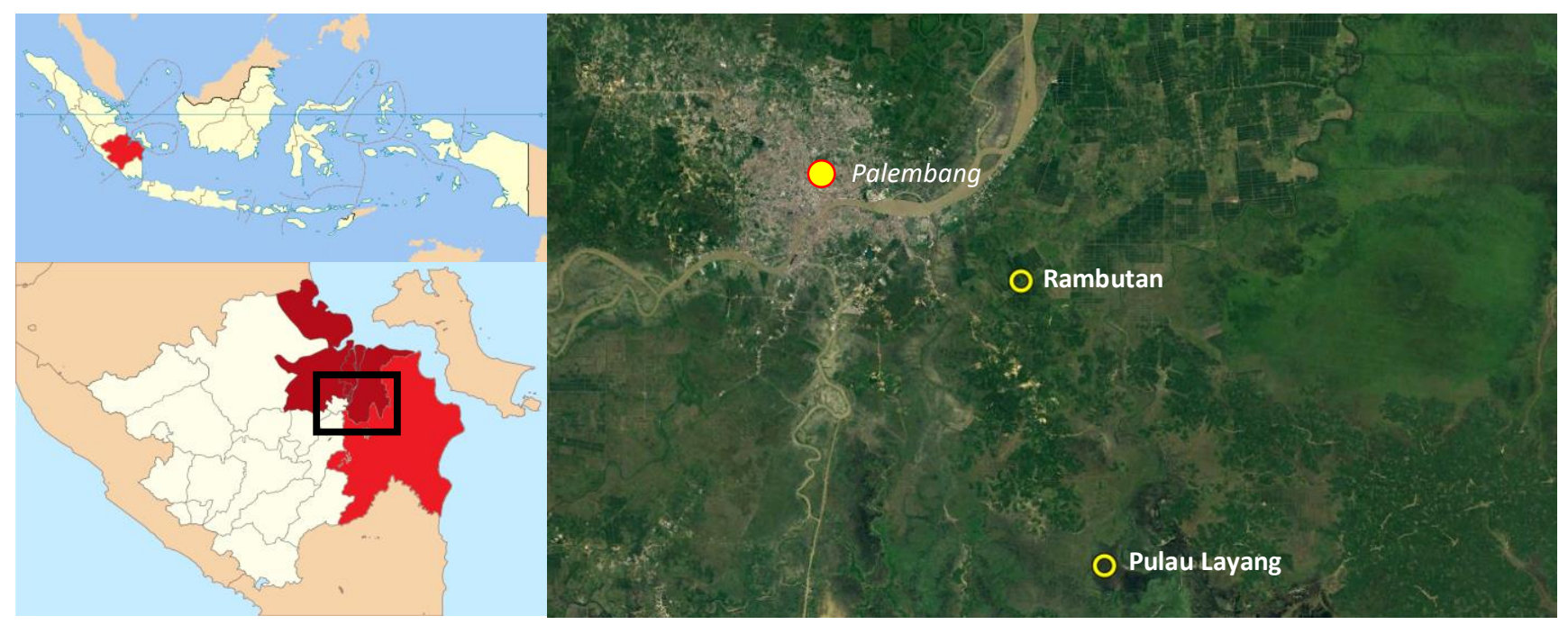

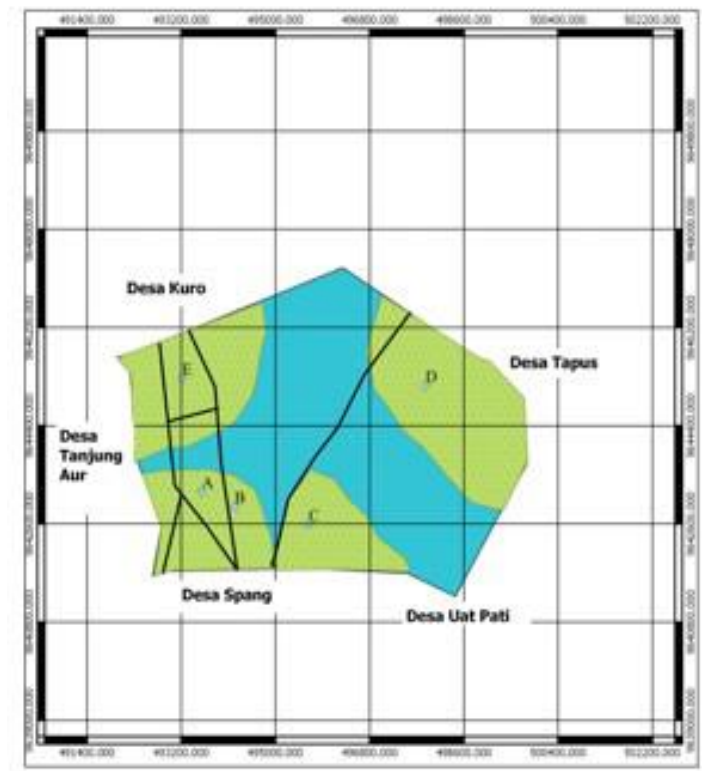

A

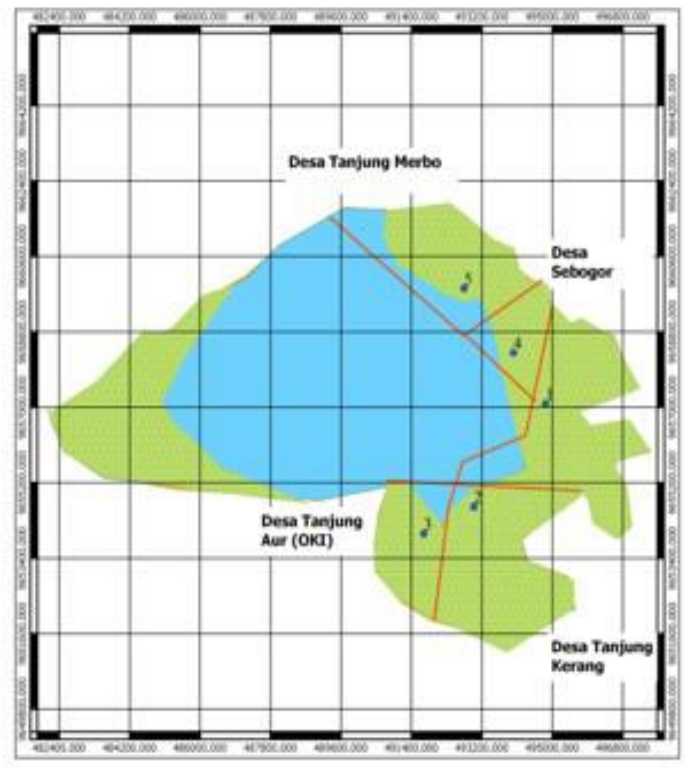

B

Figure 1. Research location in South Sumatra, Indonesia. A. Pulau Layang Village, Pampangan Sub-district, Ogan Komering Ilir District, South Sumatra. B. Rambutan Village, Rambutan Sub-district, Banyuasin District, South Sumatra, Indonesia (Muhakka et al. 2019) 


\section{Measured parameters \\ Soil analysis}

Soil sampling is done in a composite manner at a depth of $0-20 \mathrm{~cm}$. Taking the soil sample points is done by making a diagonal line in each zone and determining 5 soil sampling points to analyze chemical fertility $(\mathrm{N}, \mathrm{P}, \mathrm{K})$ and physical fertility (texture, structure, and $\mathrm{pH}$ ).

\section{Plant materials}

The sampling area is divided into five zones (A, B, C, $\mathrm{D}$ and $\mathrm{E})$ and each zone consists of 10 observation points. Samples of each type of dominant and palatable forage vegetation are collected based on the estimated age of growth, namely young age, middle age, and old age by looking at their physical appearance. Samples of each type of vegetation that have been collected, are put together until homogeneous. Samples are finely chopped, mixed until homogeneous then randomly taken as much as $1 \mathrm{~kg}$.

There are some species that are analyzed twice, in Pulau Layang and Rambutan because they appear in both areas, while the others are only analyzed once because they only appear in one area. For Sesbania exasperata, it is enough to know only its nutrient content from analysis of proximate, and the production of this grass is measly so that its potential to be buffalo's feed is measly as well, but it can be made as feed supplement. So, it is not analyzed for composition of fiber fractions (Table 3 ).

\section{Proximate analysis}

Crude protein, fiber, ether extract, and ash contents were determined based on the procedures of AOAC (1990). Crude protein. Nitrogen $(\mathrm{N})$ content was determined by using a Kjeldahl method. In this analysis, sulphuric acid was treated with a catalyst and a heating process. The organic matter of samples was then oxidized by sulfuric acid, and nitrogen was changed into an ammonium sulfate form. The remaining sulfuric acid was neutralized by $\mathrm{NaOH}$ until the solution became basic. Ammonium sulfate was then distilled in an acid medium to obtain the quantitative amount of $\mathrm{N}$. As the average protein contains $16 \%$ nitrogen, a factor $100 \%$ : $16 \%=6.25$ was used to obtain the value of crude protein (crude protein $=\mathrm{N} \% \mathrm{x}$ 6.25). Fiber. The filtered fat-free sample was used in fiber content determination. $1.25 \%$ sulfuric acid solution was added into the sample, and the mixture was heated for about 30 minutes before the residue was filtered. $1.25 \%$ $\mathrm{NaOH}$ solution was added into the precipitate, and the mixture was heated for about 30 minutes. The mixture was then filtered, and the precipitate was washed, dried, and weighed. This precipitate was burnt, and the ash was weighed. The difference between the weight of precipitate before it was burnt and the weight of the ash was referred to as fiber content. Ether extract. The dry matter sample was extracted with diethyl ether for 5 hours. At the end of the extraction process, ether evaporated and the remaining material was referred to as fat. Ash. The third part of the dry matter sample was weighed and burnt in a crucible at $550^{\circ} \mathrm{C}$ for 8 hours.

\section{Van Soest analysis}

Neutral Detergent Fiber (NDF), Acid Detergent Fiber (ADF), hemicellulose, cellulose, and lignin contents were determined by using a Van Soest method (1982).

Neutral Detergent Fiber (NDF). One gram of sample was put in a beaker glass. $50 \mathrm{ml}$ NDS solution was added into the beaker before the mixture was heated for an hour. The mixture was then filtered by using a vacuum pump and a filter glass which was previously weighed (b gram). The mixture was then washed with hot water and acetone before it was dried in an oven and let cool in a desiccator. Finally, it was weighed as c gram. NDF content was calculated by using the following formula:

$$
\% \mathrm{NDF}=\frac{\mathrm{c}-\mathrm{b}}{\mathrm{a}}
$$

Acid Detergent Fiber (ADF). One gram of sample was put in a beaker glass. $50 \mathrm{ml}$ ADS solution was added into the beaker before the mixture was heated for an hour. The mixture was then filtered by using a vacuum pump and a sintered glass filter which was previously weighed (b gram). The mixture was then washed with hot water and acetone before it was dried in an oven and let cool in a desiccator. Finally, it was weighed as c gram. Cellulose content was calculated by using the following formula:

$$
\% \text { cellulose }=-\stackrel{\text { c-d }}{\text { a }}
$$

Hemicellulose. Hemicellulose content was calculated as a difference between NDF and ADF contents as follows.

$$
\% \text { Hemicellulose }=\% \text { NDF- } \% \text { ADF }
$$

Lignin. Cellulose residue (d gram) was burnt in a furnace at $500-600^{\circ} \mathrm{C}$ for 3 hours. After that, it was left to cool and weighed (e gram). Lignin content was calculated by using the following formula:

$$
\% \text { Lignin }=\stackrel{\text { d-e }}{-----\mathrm{x} 100 \%}
$$

a

\section{Data analysis}

The data obtained were used directly to describe the nutritional value of the swamp vegetation that could be used as a roughage source. These data were then combined with those of in vitro digestibility as the basis for concluding (Syarifuddin and Wahdi 2010).

\section{RESULTS AND DISCUSSION}

\section{Soil analysis}

Results of soil analysis showed that soil at the study site had a low fertility level and was highly acidic. It also had very high organic $\mathrm{C}$ and total $\mathrm{N}$ contents, medium level of exchangeable- $\mathrm{K}$ and $\mathrm{N}$ contents, very low $\mathrm{Ca}$ and $\mathrm{Mg}$ contents, medium $\mathrm{P}$ content, and very high CEC level (Table 1). 
Table 1. Properties of soil at the study site

\begin{tabular}{lrcrc}
\hline & \multicolumn{2}{c}{ Pulau Layang } & \multicolumn{2}{c}{ Rambutan } \\
\cline { 2 - 5 } & Value & Remark & Value & Remark \\
\hline $\mathrm{pH} \mathrm{H} 2 \mathrm{O}(1: 1)$ & 5.10 & Low & 4.41 & Very low \\
$\mathrm{pH} \mathrm{KCl}(1: 1)$ & 4.39 & Very acidic & 3.99 & Very acidic \\
Organic C $(\mathrm{g} / \mathrm{kg})$ & 57.66 & Very high & 36.14 & Very high \\
Total N $(\mathrm{g} / \mathrm{kg})$ & 3.64 & Very high & 2.19 & Very high \\
Available P/Bray I $(\mathrm{mg} / \mathrm{kg})$ & 11.70 & Medium & 2.25 & Very low \\
Exchangeable K $(\mathrm{cmol} / \mathrm{kg})$ & 0.63 & Medium & 0.45 & Medium \\
$\mathrm{Na}(\mathrm{cmol} / \mathrm{kg})$ & 0.65 & Medium & 0.65 & Medium \\
$\mathrm{Ca}(\mathrm{cmol} / \mathrm{kg})$ & 1.95 & Very low & 0.73 & Very low \\
$\mathrm{Mg}(\mathrm{cmol} / \mathrm{kg})$ & 0.45 & Very low & 0.32 & Very low \\
$\mathrm{CEC}(\mathrm{cmol} / \mathrm{kg})$ & 65.25 & Very high & 43.50 & Very high \\
Exchangeable Al $(\mathrm{cmol} / \mathrm{kg})$ & 1.84 & & 2.37 & \\
Exchangeable $\mathrm{H}(\mathrm{cmol} / \mathrm{kg})$ & 0.74 & & 0.88 & \\
Texture: & & & \\
Sand $(\%)$ & 47.08 & & 46.64 & \\
Ash $(\%)$ & 31.11 & & 27.18 & \\
Clay $(\%)$ & 21.81 & & 26.18 & \\
\hline
\end{tabular}

\section{Nutrient contents of lowland swamp}

Crude protein, fiber, ether extract, and ash nutrient contents of lowland swamp vegetation found in this study are listed in (Table 2). The NDF and ADF contents of vegetation found in this study were about $40.65-79.47 \%$ and $23.66-60.33 \%$, respectively. Lowland swamp vegetation was found to have hemicellulose and cellulose contents ranging from 7.73 to $37.14 \%$ and 5.24 to $27.08 \%$, respectively. Lignin contents of lowland swamp vegetation ranged from 14.84 to $43.09 \%$ (Table 3).

There are 19 species of forage found in Pampangan buffalo pasture that have potential to be used as food for Pampangan buffalo, consisting of 17 species of grasses and herbs and 2 species of legumes (Muhakka et al. 2019). There are dominant and palatable species of swamp lowland forage vegetation having potential as buffalo feed, namely $O$. rupifogon, $H$. acutigluma, and $H$. amplexicaulis, not dominant but palatable species such as Hymenachne sp. and $N$. oleracea; dominant but non-palatable grass species (buffalo does not like it) namely P. barbatum. This grass species would be eaten by the buffaloes if there were no other species to be eaten (Muhakka et al. 2019).

\section{Discussion}

\section{Crude protein content}

Results showed that the crude protein contents of swamp green vegetation ranged from $5.26 \%$ to $20.56 \%$ with the lowest value (5.26\%) was found in $R$. corymbosa grass and the highest $(20.56 \%)$ was found in $N$. oleracea legume. $C$. digitatus grass had the highest crude protein content (15.31\%) (Table 2). This high nutritional value of C. digitatus was suspected as caused by the fact that most of this grass was found to grow in the area of buffalo pens where the soil was rich in organic matter. However, the growth of this grass was not dominant as it mostly occurred in rainy seasons.
Hymenachne amplexicaulis, $O$. rupifogon, $H$. acutigluma, and E. dulcis were found as the dominant palatable grasses containing 12.00, 10.41, 10.96, and $8.22 \%$ crude protein, respectively. Results of this study were not too different from those obtained by Rostini et al. (2014), who reported that $H$. amplexicaulis and $L$. hyssopifolia had protein contents of 10.88 and $15.92 \%$, respectively. Crude protein (CP) contents of these swamp grasses in Pulau Layang and Rambutan Villages were closed to those of prime grasses including 9.11-12.8\% CP of $P$. purpureum (Santos et al. 2013; Dahlan and Iskandar 2013; Rahman et al. 2014), 12.4\% CP of P. purpureum grass hay, $11.1 \% \mathrm{CP}$ of $P$. purpureum grass silage, $11.4 \%$ CP of $P$. purpureophoides grass hay, and $10.2 \%$ CP of $P$. purpureophoides grass silage (Santoso and Hariadi 2008). Other vegetation even had higher CP contents including $H$. acutigluma with $10.96 \%$ CP, C. roseus $15.20 \%$, N. lotus $13.22 \%$, L. hyssopifolia) $12.07 \%$, C. digitatus $15.31 \%$, and H. amplexicaulis $\mathrm{R} 12.0 \%$ (Table 2). CP contents of vegetation in this study were also higher than those of natural grasses found in coffee plantation areas $(6.95 \%)$ and pastoral areas $(6.65 \%)$ in Wulanggitang Subdistrict, East Flores District, East Nusa Tenggara Province, Indonesia as reported by Kleden et al. (2015). Meanwhile, CP content of grasses in lowlands was $8.41 \%$ (Maswada and Elzaawely 2013; Rochana et al. 2016).

This high protein content was suspected to be caused by the fact that soil organic $\mathrm{C}$ and total $\mathrm{N}$ contents in the study site were also high, namely 36.14-57.66 and 2.19-3.64 g.kg ${ }^{-1}$, respectively (Table 1). Soil organic $\mathrm{C}$ and total $\mathrm{N}$ contents affected protein content in plants. Four swamp grasses/herbs including $C$. digitatus, $C$. roseus, $N$. lotus, and L. hyssopifolia and a legume, $N$. oleracea were found to be the lowland swamp vegetation having the highest $\mathrm{N}$ contents of $15.31,15.20,13.22,12.07$, and $20.56 \%$, respectively. 
Table 2. Crude protein, fiber, ether extract, and ash contents (\%) of lowland swamp vegetation

\begin{tabular}{|c|c|c|c|c|c|c|c|}
\hline Latin name & Family & $\begin{array}{c}\text { Origin } \\
\text { (village) }\end{array}$ & Local name & $\begin{array}{c}\text { Crude } \\
\text { protein }\end{array}$ & Fiber & $\begin{array}{c}\text { Ether } \\
\text { extract }\end{array}$ & Ash \\
\hline Catharanthus roseus & Apocynaceae & Pulau Layang & Tapak dara & 15.20 & 11.18 & 1.29 & 12.53 \\
\hline Cyperus digitatus & Cyperaceae & Rambutan & Kasuran & 15.31 & 14.76 & 1.42 & 25.19 \\
\hline Digitaria fuscescens & Poaceae & Rambutan & Kerak maling/pasiran & 12.00 & 15.64 & 1.24 & 16.26 \\
\hline Eichhornia crassipes & Pontederiaceae & Pulau Layang & Eceng gondok & 8.61 & 20.66 & 0.84 & 14.22 \\
\hline Eleocharis dulcis-P & Cyperaceae & Pulau Layang & Purun tikus & 8.22 & 25.72 & 0.48 & 15.13 \\
\hline Eleocharis dulcis- $\mathrm{R}$ & Cyperaceae & Rambutan & Purun tikus & 6.63 & 24.52 & 1.69 & 10.24 \\
\hline Hymenachne acutigluma-P & Poaceae & Rambutan & Kumpai tembaga & 10.96 & 23.73 & 1.77 & 10.30 \\
\hline Hymenachne acutigluma-R & Poaceae & Pulau Layang & Kumpai tembaga & 6.86 & 30.26 & 2.22 & 7.88 \\
\hline Hymenachne amplexicaulis-P & Poaceae & Pulau Layang & Kumpai minyak & 9.21 & 21.91 & 2.82 & 13.96 \\
\hline Hymenachne amplexicaulis- $\mathrm{R}$ & Poaceae & Rambutan & Kumpai minyak & 12.00 & 15.64 & 1.24 & 16.26 \\
\hline Hymenachne sp. & Poaceae & Pulau Layang & Kumpai merah & 8.52 & 21.20 & 1.30 & 12.88 \\
\hline Ipomoea aquatica & Convolvulaceae & Pulau Layang & Kangkung merah & 8.95 & 14.34 & 2.24 & 10.39 \\
\hline Leersia hexandra & Poaceae & Pulau Layang & Bento rayap & 5.35 & 27.57 & 2.06 & 5.63 \\
\hline Ludwigia hyssopifolia & Onagraceae & Pulau Layang & Cecengkehan & 12.07 & 11.01 & 1.66 & 9.09 \\
\hline Neptunia olerancia & Fabaceae & Pulau Layang & Kemon air & 20.56 & 15.03 & 2.92 & 7.31 \\
\hline Nymphaea lotus & Nymphaeaceae & Pulau Layang & Telepuk gajah & 13.22 & 11.45 & 2.84 & 10.30 \\
\hline Oryza rupifogon-P & Poaceae & Pulau Layang & Kumpai padi & 7.93 & 23.30 & 1.60 & 16.25 \\
\hline Oryza rupifogon- $\mathrm{R}$ & Poaceae & Rambutan & Kumpai padi & 10.41 & 21.59 & 2.49 & 11.92 \\
\hline Polygonum barbatum & Poaceae & Pulau Layang & Are bolong & 7.53 & 16.60 & 1.57 & 8.40 \\
\hline Rhynchospora corymbosa & Cyperaceae & Pulau Layang & Berondong & 5.26 & 22.27 & 1.48 & 14.84 \\
\hline Sesbania exasperata & Fabaceae & Rambutan & Mutiara & 18.27 & 11.22 & 1.86 & 19.47 \\
\hline
\end{tabular}

Note: P: Pulau Layang Village; R: Rambutan Village

Table 3. Composition of fiber fractions of green vegetation in lowland swamp: NDF, ADF, hemicellulose, cellulose, and lignin (\%).

\begin{tabular}{|c|c|c|c|c|c|c|c|}
\hline Latin name & Family & $\begin{array}{l}\text { Origin } \\
\text { (village) }\end{array}$ & NDF & ADF & $\begin{array}{c}\text { Hemi- } \\
\text { cellulose }\end{array}$ & Cellulose & Lignin \\
\hline Catharanthus roseus & Apocynaceae & Pulau Layang & 47.79 & 39.67 & 8.12 & 16.96 & 22.71 \\
\hline Cyperus digitatus & Cyperaceae & Rambutan & 58.90 & 36.93 & 21.97 & 5.24 & 31.68 \\
\hline Digitaria fuscescens & Poaceae & Rambutan & 65.43 & 33.56 & 31.87 & 12.11 & 21.45 \\
\hline Eichhornia crassipes & Pontederiaceae & Pulau Layang & 62.77 & 41.83 & 20.94 & 10.22 & 31.60 \\
\hline Eleocharis dulcis-P & Cyperaceae & Pulau Layang & 69.57 & 49.83 & 19.74 & 21.80 & 28.04 \\
\hline Eleocharis dulcis- $\mathrm{R}$ & Cyperaceae & Rambutan & 75.73 & 54.91 & 20.82 & 19.71 & 35.20 \\
\hline Hymenachne acutigluma-P & Poaceae & Pulau Layang & 75.89 & 50.60 & 25.29 & 12.25 & 38.34 \\
\hline Hymenachne acutigluma- $\mathrm{R}$ & Poaceae & Rambutan & 64.72 & 46.38 & 18.34 & 16.01 & 30.37 \\
\hline Hymenachne amplexicaulis-P & Poaceae & Pulau Layang & 65.31 & 38.92 & 26.39 & 8.29 & 30.63 \\
\hline Hymenachne amplexicaulis- $\mathrm{R}$ & Poaceae & Rambutan & 65.32 & 39.45 & 25.87 & 9.75 & 28.67 \\
\hline Hymenachne sp. & Poaceae & Pulau Layang & 60.14 & 28.40 & 31.74 & 8.64 & 19.76 \\
\hline Ipomoea aquatica & Convolvulaceae & Pulau Layang & 41.40 & 26.17 & 15.23 & 6.32 & 19.85 \\
\hline Leersia hexandra & Poaceae & Pulau Layang & 79.47 & 42.33 & 37.14 & 25.88 & 33.92 \\
\hline Ludwigia hyssopifolia & Onagraceae & Pulau Layang & 40.64 & 32.91 & 7.73 & 8.39 & 24.52 \\
\hline Neptunia olerancia & Fabaceae & Pulau Layang & 62.31 & 45.44 & 16.87 & 27.08 & 18.36 \\
\hline Nymphaea lotus & Nymphaeaceae & Pulau Layang & 46.05 & 23.66 & 22.39 & 8.82 & 14.84 \\
\hline Oryza rupifogon-P & Poaceae & Pulau Layang & 71.13 & 60.33 & 10.80 & 17.23 & 43.09 \\
\hline Oryza rupifogon- $\mathrm{R}$ & Poaceae & Rambutan & 65.49 & 46.19 & 19.30 & 14.96 & 31.24 \\
\hline Polygonum barbatum & Poaceae & Pulau Layang & 61.27 & 48.46 & 12.81 & 20.28 & 28.18 \\
\hline Rhynchospora corymbosa & Cyperaceae & Pulau Layang & 65.29 & 44.64 & 20.65 & 16.08 & 28.56 \\
\hline
\end{tabular}

Note: P: Pulau Layang Village; R: Rambutan Village

\section{Fiber contents}

Fiber contents of lowland swamp green vegetation ranged from 11.01 to $30.26 \%$, with the lowest content found in L. hyssopifolia and the highest in H. acutigluma ${ }^{\mathrm{P}}$. Four vegetation including $L$. hyssopifolia, $C$. roseus, $S$. exasperata, and $N$. lotus were found to have the lowest fiber contents of $11.01,11.18,11.22$, and $11.45 \%$, respectively (Table 2). These results were almost similar to those found by Ali et al. (2012) who reported that the fiber contents of roughage in a pasture ranged from 7.20 to $34.98 \%$. These researchers found that the fiber content of Leersia hexandra was $27.40 \%$ which was very close to that $(27.57 \%)$ of the same vegetation in this study. Meanwhile, Rostini et al. (2014) reported that the fiber contents of swamp vegetation in South Kalimantan ranged from 14.84 to $29.35 \%$ with the lowest content found in Paspalum sp. and the highest in L. adscendens. These figures were lower than those found by Kleden et al. (2015) who revealed that 
nature grasses in a coffee plantation area and pasture in Wulanggitang, East Flores contained 34.57 and $35.59 \%$ of fiber. They also found that the lowest fiber content was found in L. peploides and the highest in I. rugosum. Fiber contents reported by Kleden et al. (2015) were higher than the results reported by Ahmed et al. (2013) with a fiber content of $29.32 \%$ in D. aegyptium plants. A previous study showed that fermented I. rugosum, H. amplexicaulis, and $O$. rufipogon had fiber contents of 29.27, 29.57, and $33.07 \%$, respectively (Muhakka et al. 2015).

The fiber content of E. crassipes in this study (20.66\%) was lower than those found by Hossain et al. (2015), Tham and Uder (2015), and Make et al. (2016). In addition, the fiber content of $E$. crassipes in this study was lower than those of Azolla, another water plant, ranging from 13.19 to 16.54\% (Kathirvelan et al. 2015; Anitha et al. 2016) and 9.25 to $13.25 \%$ (Ahmed et al. 2016). These fiber contents of Azolla equaled to those of L. hyssopifolia (11.01\%), C. roseus (11.18\%), S. exasperata (11.22\%), N. lotus $11.45 \%$, and I. aquatica (14.34\%) found in this study. Fiber contents of swamp green vegetation found in this study indicated that they were potential to be used as feed for Pampangan buffaloes.

\section{Ether extract contents}

Lowland swamp vegetation in this study was found to have ether extract (EE) contents of about $0.48-2.92 \%$. The lowest EE content was found in E. dulcis, while the highest was found in $N$. oleracea. Four vegetation of lowland swamp including $N$. lotus $(2.84 \% \mathrm{EE}), H$. amplexicaulis $(2.82 \% \mathrm{EE})$, O. rufipogon $(2.49 \% \mathrm{EE})$, and I. aquatica $(2.24 \% \mathrm{EE})$ were revealed to have the highest ether extract contents (Table 2). Results of this study were lower than those found by Rostini et al. (2014), reporting about 0.61$3.67 \%$ of EE contents in swamp vegetation in South Kalimantan with the lowest found in L. hyssopifolia and the highest in O. rufipogon. EE contents of lowland swamp vegetation were $1.40-1.91 \%$ for grasses and $1.36-2.95 \%$ for legumes (Asep et al. 2012) and those of grasses in a pasture for buffaloes in Pulau Moa were 1.95-2,41\% (Eoh 2014). In other studies, grasses in a natural pasture in North Lore, Poso District had EE contents of 2.12-2.34\% (Damry 2009) and those in Sabana Timur Barat pasture in the rainy season to the end of dry season had an average EE content of $1.91 \%$ (Manu 2013). A study by Se'u et al. (2015) revealed an EE content of $1.07 \%$ in grasses in a pasture in Timor Tengah Selatan District, Indonesia. Another work by Kleden et al. (2015) showed that vegetation in a natural pasture and a coffee plantation area had EE contents of 1.23 and $1.35 \%$, respectively.

Vegetation found in this study had EE contents equaled to those of prime grasses including $P$. purpureum grass and $P$. purpureophoides grass preserved in the form of hay and silage. $P$. purpureum grass hay and silage had EE contents of 1.9 and $2.6 \%$, respectively, while those of $P$. purpureophoides grass had EE contents of 1.6 and 2.4\%, respectively (Santoso and Hariadi 2008; Ukpabi et al. 2015). EE contents of some species of ruminant roughages were found to be about 1.2-4.1\% (Ahmed et al. 2013). Dominant swamp roughages including $H$. amplexicaulis and $O$. rufipogon had EE contents of 2.82 and $2.49 \%$, respectively and they were palatable and potential to be used as feed for Pampangan buffaloes.

\section{Ash contents}

Ash contents of green vegetation in lowland swamp ranged from 5.63 to $25.19 \%$. Four types of vegetation with the highest ash contents included $C$. digitatus $(25.19 \%), S$. exasperata (19.47\%), H. amplexicaulis (16.26\%), and $O$. rufipogon $^{\mathrm{P}}(16.25 \%)$. Meanwhile, L. hexandra was found to have the lowest ash content of $5.63 \%$ (Table 2). Ash contents of vegetation found in this study were higher than those of swamp vegetation in South Kalimantan of 2.18$3.28 \%$ during the high tidal season and 3.23-9.83\% during the low tidal season (Rostini et al. 2014). P. purpureum grass was indicated to have varied ash contents of $4.4 \%$ (Dahlan and Iskandar 2013), 0.95-1.1\% (Ukpabi et al. 2015), 9.59\% (Nuhuyanan 2010), and 18\% (Araica et al. 2009). Meanwhile, the ash content of grasses in lowland areas ranged from 6.32 to $8.91 \%$ (Richmond et al. 2015; Mako et al. 2016; Norman et al. 2013; Maswada et al. 2013). Alam et al. (2015) found that B. mutica had an ash content of $4.20-4.89 \%$ and rice straw had $6.63 \%$.

Roughages were found to have average ash contents of $7.28 \%$ in a pasture for buffaloes in Pulau Moa (Eoh 2014), 9.82-10.14\% in Lore Utara, Poso District (Damry 2009), $11.51 \%$ in a pasture during the rainy season until the end of dry season in Sabana Timur Barat (Manu 2013), and 8.11 and $8.22 \%$ in a natural pasture and a coffee plantation area, respectively (Kleden et al. 2015). Differences in these ash contents were suspected to be caused by differences in plant species (internal factor) and environmental differences, particularly seasonal differences (external factor). In a dry season, $\mathrm{pH}$ levels in lowland swamp areas were found to be 3.9-4.8, causing a decreased supply of nutrients, especially total $\mathrm{N}$ and $\mathrm{K}$, to the soil. This decreased supply of nutrients led to lowered nutrients contained in plants (Rostini et al. 2014). This was in line with what was stated by Gutteridge and Shelton (1994) that nutrient content in plants was affected by soil nutrient content. In addition, in acidic soil conditions, activities of $\mathrm{Fe}, \mathrm{Al}$, and $\mathrm{Mn}$ increased which might cause toxicity in plants (Tjondronegoro and Gunawan 2000).

\section{NDF and ADF contents}

Neutral Detergent Fiber (NDF) depicts plant cell walls consisting of hemicellulose, cellulose, and lignin. NDF is part of fiber that is not dissolved in neutral detergent representing the component of fiber not dissolving in plant cell wall materials. NDF content of a feed affects the ability of ruminants to consume the feed. Acid Detergent Fiber (ADF) represents parts of the plant cell wall bond to cellulose and lignin. ADF content is related to energy content and higher $\mathrm{ADF}$ content results in lowered digestible energy content (Van Soest 1982).

The NDF and ADF contents of vegetation found in this study were about $40.65-79.47 \%$ and $23.66-60.33 \%$, respectively. Lowest NDF contents were found in $L$. hyssopifolia $(40.65 \%)$, I. aquatica $(41.40 \%)$, N. lotus $(46.05 \%)$, and $C$. roseus $(47.79 \%)$. In contrast, highest 
NDF content of $79.47 \%$ was found in L. hexandra. Lowest ADF contents were found in N. lotus $(46.05 \%)$, I. aquatica (26.17\%), Hymenachne sp. (28.40\%), L. hyssopifolia $(32.91 \%)$. Meanwhile, the highest ADF content of $60.33 \%$ was found in (O. rufipogon ${ }^{\mathrm{P}}$ (Table 3$)$. NDF and ADF contents of vegetation found in this study were lower than those of Asep et al. (2012) who reported that the NDF contents of swamp green vegetation in a pasture for buffaloes were about $91.73-93.45 \%$ in grasses and 68.11 $90.93 \%$ in legumes and the $\mathrm{ADF}$ content of grasses was $51.6-86.8 \%$. It was shown in other studies that NDF and $\mathrm{ADF}$ contents of roughages in a pasture during the rainy season to the end of the dry season in Sabana Timur Barat were on average 65.9 and $43.29 \%$, respectively (Manu 2013). Vegetation in a natural pasture and a coffee plantation area had NDF contents of 74.89 and $72.37 \%$ and ADF contents of 57.22 and $55.15 \%$, respectively (Kleden et al. 2015). Meanwhile, swamp vegetation in South Kalimantan had average NDF and ADF contents of 55.97 and $37.87 \%$, respectively, during the high tidal season and 81.44 and $60.86 \%$ respectively, during the low tidal season (Rostini et al. 2014).

NDF and ADF contents of roughages in the BPTU-HPT Padang Mengatas area were found to be 75.62 and $45.96 \%$, respectively in the rain season and 69.35 and $38.66 \%$, respectively in the dry season (Muhajirin et al. 2017). NDF and ADF contents of E. crassipes in this study were 62.77 and $41.83 \%$, respectively. These figures were close to those of E.crassipes plants studied by Tham (2015) with NDF and ADF contents of 63.9 and $34.68 \%$ and by Tham and Uden (2015) with NDF and ADF contents of 52.1 and $30.7 \%$, respectively. Other studies conducted by Ahmed et al. (2016), Anitha et al. (2016), and Nampoothiri (2017) showed that Azolla sp. had NDF and ADF contents of 53.8$54.85 \%$ and $36.57-37.0 \%$, respectively. Meanwhile, NDF and ADF contents of $P$. purpureum were found to be 55.8 and 46.5\% (Dahlan and Iskandar 2013) and 84.25 and $64.07 \%$ (Nuhuyanan 2010), respectively. These figures equaled to the NDF and ADF contents of $H$. acutigluma (64.72 and 46.38\%), H. amplexicaulis (65.31 and 38.92), and $P$. barbatum (61.27 and $48.46 \%)$. This indicated that lowland swamp vegetation had fiber fraction nutritional quality which was not less than that of prime grasses including $P$. purpureum and $P$. purpureophoides.

In this study, NDF and ADF contents of lowland swamp vegetation were $40.65-79.47 \%$ and $23.66 \%$ $60.33 \%$, respectively. These figures were still within the ranges of NDF and ADF contents of prime grasses such as $P$. purpureum which had NDF and ADF contents of 55.8 and 46.5\% (Dahlan and Iskandar 2013) and 84.25 and $64.07 \%$ (Nuhuyanan 2010), respectively. In the rumen, NDF degradation is higher than that of ADF as NDF contains hemicellulose fraction which is more soluble (Church and Pond 1986). NDF content has a negative correlation with its degradation rate (Varga et al. 1983) and higher NDF content decreases dry matter digestibility of feed (NRC 1988). Cellulose is an ADF component that is easy to digest while lignin is hard to digest as it contains double bonds. Higher lignin content decreases feed digestibility (Sutardi et al. 1980).

\section{Hemicellulose and cellulose contents}

Lowland swamp vegetation was found to have hemicellulose and cellulose contents ranging from 7.73 to $37.14 \%$ and 5.24 to $27.08 \%$, respectively. Four green vegetation with the highest hemicellulose contents were $L$. hexandra) (37.14\%), D. fuscescens (31.87\%), Hymenachne sp. (31.74\%), and H. amplexicaulis $(26.39 \%)$. In contrast, the lowest hemicellulose content was found in $L$. hyssopifolia (7.73\%). Highest cellulose contents were found in (N. oleracea (27.08\%), L. hexandra (25.88\%), E. dulcis $(21.80 \%)$, and P. barbatum (20.28\%). Meanwhile, C.digitatus had the lowest cellulose content of $5.24 \%$ (Table 3). Results of this study were in line with those of a study conducted by Asep et al. (2012) who reported the hemicellulose and cellulose contents of lowland swamp green vegetation ranging from 7.89 to $31.55 \%$ and 30.85 to $63.35 \%$, respectively. They also found that $O$. rufipogon had $31.55 \%$ hemicellulose content which was higher than those of $10.80-19.30 \%$ in this study (Table 4). Swamp vegetation in South Kalimantan had hemicellulose contents of $0.65-25.85 \%$ in high tidal season and 5.37-40.09\% in low tidal season. Cellulose contents in high and low tidal seasons were about 20.07-34.03\% and 7.90-38.31\%, respectively (Rostini et al. 2014). Various water plants including Azolla, which was used as animal feed, had hemicellulose and cellulose contents of 10.20 and $12.76 \%$ (Nampoothiri 2017), $1.15-10.20 \%$ and $12.76 \%$ (Nampoothiri 2017), respectively. Roughages in BPTUHPT Padang Mengatas, Indonesia had hemicellulose and cellulose contents of 29.79 and $33.62 \%$ in the rain season and 30.69 and $31.64 \%$ in the dry season, respectively (Muhajirin et al. 2017). P. purpureum was found to contain $21.18 \%$ hemicellulose and $43.32 \%$ cellulose (Nuhuyanan 2010) and $35.3 \%$ cellulose (Dahlan and Iskandar 2013). In a study conducted by Archimede et al. (2010), hay was found to have $37.7 \%$ hemicellulose and $35.7 \%$ cellulose. Based on the above findings, it was suggested that hemicellulose (7.73-37.14\%) and cellulose (5.24-27.08\%) contents of lowland swamp vegetation in this study were within normal ranges and this vegetation was potential to be used as feed for Pampangan buffaloes.

\section{Lignin contents}

Lignin contents of lowland swamp vegetation ranged from 14.84 to $43.09 \%$. Four vegetation including N. lotus, N. oleracea, Hymenachne sp., and I. aquatica were found to have the lowest lignin contents of 14.84, 18.36, 19.76, and $19.85 \%$, respectively, while the highest lignin content of $43.09 \%$ was found in O. rufipogon ${ }^{\mathrm{P}}$ (Table 3). Lignin contents in this study were higher than that obtained by Rostini et al. (2014) who reported the lignin contents of swamp vegetation in South Kalimantan were about 2.8$17.59 \%$ in high tidal season with that of $H$. amplexicaulis as the lowest and that of $O$. rufipogon as the highest and $10.06-61.12 \%$ in low tidal season with that of O. rufipogon as the lowest and that of $H$. amplexicaulis as the highest. Lignin contents of $O$. rufipogon ${ }^{\mathrm{R}}(31.24 \%)$ and $O$. rufipogon $^{\mathrm{P}}(43.09 \%)$, L. hexandra $(33.92 \%)$, and $E$. crassipes $(31.60 \%)$ (Table 3 ) found in this study were higher those of (18.27\%) and L. hexandra (17.96\%) found 
by Asep et al. (2012) and E. crassipes (8.17\%) found by Tham (2015). In other studies, Azolla was found to have lignin contents of $5.7 \%$ (Ahmed et al. 2016) and $28.24 \%$ (Nampoothiri 2017). Meanwhile, lignin contents of $P$. purpureum grass were found to be $15.37 \%$ (Nuhuyanan 2010) and 11.2\% (Dahlan and Iskandar 2013).

Differences in lignin contents in green vegetation are suspected to be caused by differences in plant species, plant ages, and environmental factors including seasons (rain or dry season), tidal seasons, and fertility levels of the soil where the vegetation grow. In cell walls, cellulose is a bond with hemicellulose and lignin. The animals cannot digest lignin and its molecular structure is different from other carbohydrates as it contains carbon and nitrogen of only 1 $5 \%$. Hemicellulose consists of pentose, hexose, uronic acid, and pectin substance. Pectin is a carbohydrate that is composed of uronic acid, galactose, arabinose, xylose, and methanol. Cellulose is degradable by microorganisms and functions as the source of volatile fatty acids. Young grasses (roughages) contain less than 5\% lignin and $80 \%$ of their cellulose is degradable. On the contrary, in old roughages, lignin content may reach up to $10 \%$ causing a decrease in cellulose digestibility by up to $50 \%$ (Prawirokusumo 1994).

Based on the results of the study, it was concluded that: (i) the highest protein $(20.56 \%)$ and crude fat $(2.92 \%)$ contents were found in $N$. oleracea. The highest ash content $(25.19 \%)$ was found in $C$. digitatus, while the lowest $(11.01 \%)$ was found in L. hyssopifolia. The lowest NDF content $(40.64 \%)$ was found in L. hyssopifolia and the highest hemicellulose content $(37.14 \%)$ was found in $L$. hexandra. $N$. lotus had the lowest $\operatorname{ADF}(23.66 \%)$ and lignin $(14,84 \%)$ contents. $N$. olerancia contained the highest cellulose level of $27.08 \%$. (ii) The best nutritional values were found in $C$. digitatus and L. hyssopifolia. (iii) Dominant and palatable swamp roughages with good nutrient contents included $H$. acutigluma, $H$. amplexicaulis, $O$. rufipogon, $P$. barbatum, and $E$. dulcis.

\section{ACKNOWLEDGMENTS}

The author expresses his deepest gratitude to the Rector of Sriwijaya University through the Chair of the Institute for Research and Community Services funding this research in accordance with the Competitive Leading Research Contract of Sriwijaya University Number: 988/UN9.3.1/PP/2017, dated 21 July 2017.

\section{REFERENCES}

Ahmed HA, Ganai A.M, Beigh YA, Sheikh GG, Reshi PA. 2016 Performance of growing sheep on Azolla based diets. Indian J Anim Res 50 (5): 721-724.

Alam MR, Haque MM, Sumi KR, Ali MM. 2015. Proximate composition of para-grass (Brachiaria mutica) produced in integrated fish-fodder culture system. Bangladesh J Anim Sci 44 (2): 113-119.

Ali AIM, Sandi S, Muhakka, Riswandi. 2012. Kualitas hijauan pakan di rawa lebak padang penggembalaan kerbau pampangan. Proc InSINAS 2012: 307-312. [Indonesian]
Anitha KC, Rajeshwari YB, Prasanna SB, Shree JS. 2016. Nutritive evaluation of Azolla as livestock. J Exp Biol Agric Sci 4 (6): 670-674.

AOAC. 1990. Official Methods of Analysis. 15 ${ }^{\text {th }}$ ed., Association of Official Analytical Chemists, Washington, DC.

Araica BM, Sporndly E, Sanchez NR, Norell L, Sporndly R. 2009. Silage quality when Moringa oleifera is ensiled in mixtures with elephant grass, sugar cane and molasses. Grassl For Sci 64: 364-373.

Archimede H, Gonzales-Garcia E, Despois P, Etienne T, Alexandre G. 2010. Substitution of corn and soybean with green banana fruits and Gliricidia sepium forage in sheep fed hay-based diets: effects on intake, digestion and growth. J Anim Physiol Anim Nutr 94 (2010): 118-128.

BPS. 2010. Luas lahan rawa di Indonesia. Badan Pusat Statistik \& Direktorat Jendral Tanaman Pangan, Departemen Pertanian, Jakarta. [Indonesian]

BPS. 2014. Sumatera Selatan dalam Angka 2014. Badan Pusat Statistik) Provinsi Sumatera Selatan, Palembang. [Indonesian]

Brazle FK, Kilgore GI, Fauzett MR. 2000. Effect of season on grazing native-grass pastures. Prof Anim Sci 16: 15-28.

Church DC, Pond WG. 1986. Digestive Animal Physiology and Nutrition. 2nd. Prentice Hall, Englewood Cliff, New York.

Dahlan I, Iskandar MNZ. 2013. Use of plantain peels (Musa paradisiaca) as a fibrous feed substitute for napier grass (Pennisetum purpureum) in rusa deer (Cervus timorensis) ratio under captivity. J Anim Sci 3 (9): 472-480.

Damry. 2009. Produksi dan kandungan nutrisi hijauan padang penggembalaan alam di Kecamatan Lore Utara Kabupaten Poso. J Agrol 16 (4): 296-300. [Indonesian]

Dinas Peternakan Sumatera Selatan. 2014. Statistik Peternakan Provinsi Sumatera Selatan Tahun Anggaran 2015. Dinas Peternakan Sumatera Selatan, Palembang. [Indonesian]

Eoh M. 2014. Kapasitas tampung dan komposisi zat-zat makanan padang penggembalaan ternak kerabau di Pulau Moa. Agrinimal 4 (2): 77-82.

Gutteridge RC, Shelton HM. 1994. The Role of Forage Tree Legumes in Cropping and Grazing System. FAO, Rome, Italy.

Hossain MdE, Sikder H, Kabir MdH, Sarma SM. 2015. Nutritive value of water hyacinth (Eichhornia crassipes). Online J Anim Feed Res 5 (2): 40-44.

Kathirvelan C, Banupriya S, Purushothaman MR. 2015. Azolla-an alternate and sustainable feed for livestock. Intl J Sci Environ 4 (4): 1153-1157.

Kleden MM, Ratu MRD, Randu MDS. 2015. Kapasitas tampung hijauan pakan dalam areal perkebunan kopi dan padang rumput alam di Kabupaten Flores Timur Nusa Tenggara Timur. J Zootek 35 (2): 340350. [Indonesian]

Mako AA, Akinwande VO, Anurudu NF, Ogunwole OA. 2016. Evaluation of nutritive value of water hyacinth (Eichhornia crassipes) and guinea grass (Panicum maximum) mixture as animal feed in the tropics. 2016. Bull Anim Hith Prod Afr 64: 463-473.

Manu AE. 2013. Produktivitas padang penggembalaan sabana Timor Barat. J Pastura 3 (1): 25-29. [Indonesian]

Maswada HF, Elzaawely AA. 2013. Nutritive value of Stipagrostis lanata (Forssk.) de Winder as a feed for livestock. Asian J Crop Sci 5 (2): 216-221.

Muhajirin, Despal, Khalil. 2017. Pemenuhan kebutuhan nutrien sapi potong bibit yang digembalakan di Padang Mengatas. Buletin Makanan Ternak 104 (1): 9-20. [Indonesian]

Muhakka, Suwignyo RA, Budianta D, Yakup. 2019. Vegetation analysis of no-tidal swampland in South Sumatra, Indonesia and its carrying capacity for Pampangan buffalo pasture. Biodiversitas 20 (4): 10771086.

Muhakka, Wijaya A, Ammar M. 2015. Nutritional dried matter, crude protein and crude fiber on lowland tidal grass fermented by probiotic microorganisms for use Bali cattle feed. J Anim Prod 17 (1): 24-29.

Mulyani A, Sarwani M. 2013. Karakteristik dan potensi lahan sub optimal untuk pengembangan pertanian di Indonesia. J Sumber Daya Lahan 7 (1): 47-55. [Indonesian]

Nampoothiri VM. 2017. Aquatic plants and marine waste as animal feed. Sch J Agric Vet Sci 4 (6): 249-254.

Norman HC, Master DG, Barrentt-Lennard EG. 2013. Halophytes as forage in saline landscapes: Interaction between plant genotype and environment change their feeding value to ruminants. Environ Exp Bot 92 (2013): 96-109.

NRC. 1988. Nutrition Requirement of Beef Cattle. 6th rev ed. National Research Council, Washington, DC 
Nuhuyanan LE. 2010. Pengaruh pemberian wafer rumput gajah dengan perekat fermented moter liquor (FML) dan tetes (molasses) terhadap konsumsi pakan, kecernaan zat-zat makanan dan kenaikan berat badan sapi bali jantan. J Ilmu Peternakan 5 (2): 111-117. [Indonesian]

Prawirokusumo S. 1994. Ilmu Gizi Komperatif. BPFE, Yogyakarta. [Indonesian]

Rahman MM, Abdullah RB, Wan Khadijah WE, Nakagawa T, Akashi R. 2014. Feed intake and growth performance of goats offered Napier grass (Pennisetum purpureum) supplemented with concentrate pellet and soya waste. Sain Malaysiana 43 (7): 967-971.

Richmond AS, Wylie ARG, Laidlaw AS, Lively FO. 2015. Methane emissions from beef cattle grazing on semi-natural upland and improved lowland grasslands. Animal 9 (1): 130-137.

Rostini T, Abdullah L, Wiryawan KG, Karti PDMH. (2014). Production and nutrition potency of swamp local forage in South Kalimantan as ruminant feed. Glob J Anim Sci Livestock Prod Anim Breed 2 (2) 107-113.

Santoso dan Hariadi BTj. 2008. Komposisi kimia, degradasi nutrien dan produksi gas metana in vitro rumput tropika yang diawetkan dengan metode silase dan hay. J Media Peternakan 31 (2): 128-137.
Se'u VE, Karti PDMH, Abdullah L. 2015. Botanical composition, grass production, and carrying capacity of pasture in Timor Tengah Selatan District. J Media Peternakan 38 (3): 176-182.

Sutardi T, Pratiwi SH, Adnan A, Nuraini S. 1980. Peningkatan pemanfaatan jerami padi melalui hidrolisa basa, suplementasi urea dan belarang. Buletin Makanan Ternak No. 6, Balai Besar Penelitian Veteriner, Bogor. [Indonesian]

Tham HoT, Uden P. 2015. Effect of freshwater Hyacinth (Eichhornia crassipes) on intake and digestibility in cattle fed rice straw and molasses-urea cake. Nova J Eng Appl Sci 4 (1): 1-8.

Tham HoT. 2015. Utilisation of water hyacinth as animal feed. Nova J Eng Appl Sci 4 (1): 1-6.

Tjondronegoro AD, Gunawan A. 2000. Beberapa jenis gulma di lahan pasang surut pada tingkat kemasaman tanah yang berbeda. Pros. Seminar Nasional: P. 247-254. [Indonesian]

Van Soest PJ. 1982. Nutritional Ecology of the Ruminant: Ruminant Metabolism, Nutritional Strategies the Cellulolytic Fermentation and the Camisthy of Forages and Palm Fiber. Cornell University, O \& B Books Inc., USA.

Varga GA, Hoover WH. 1983. Rate and extent of NDF of feedstuff insitu. J Dairy Sci 66: 2109. 